\title{
Ovarian Surface Epithelium in Patients with Severe Ovarian Infertility: A Potential Source of Cells Expressing Markers of Pluripotent/Multipotent Stem Cells
}

\author{
Irma Virant-Klun, ${ }^{1}$ Thomas Skutella, ${ }^{2}$ Martin Stimpfel, ${ }^{1}$ and Jasna Sinkovec ${ }^{1}$ \\ ${ }^{1}$ Department of Obstetrics and Gynecology, University Medical Centre Ljubljana, 1000 Ljubljana, Slovenia \\ ${ }^{2}$ Institute for Anatomy and Cell Biology, Faculty of Medicine, University of Heidelberg, 69120 Heidelberg, Germany \\ Correspondence should be addressed to Irma Virant-Klun, irma.virant@kclj.si
}

Received 6 June 2011; Accepted 31 August 2011

Academic Editor: Matthew B. Wheeler

Copyright (C) 2011 Irma Virant-Klun et al. This is an open access article distributed under the Creative Commons Attribution License, which permits unrestricted use, distribution, and reproduction in any medium, provided the original work is properly cited.

\begin{abstract}
The aim of this study was to confirm the presence of stem cells in the ovarian surface epithelium of patients with premature ovarian failure and no mature follicles and oocytes. In these patients, small round cells of unknown origin expressing SOX-2 marker of pluripotency were observed among the epithelial cells just after the ovarian surface epithelium scraping. These cells were an integral part of the ovarian surface epithelium. When the scraped cells were cultured in a medium with added follicular fluid to provide some ovarian niche, primitive oocyte-like cells and typical round-shaped cell clusters positively stained on alkaline phosphatase, and markers of pluripotency, such as SOX-2 and SSEA-4, were developed. These markers were expressed early and also later in the culture. Single oocyte-like cells expressed genes OCT4A, SOX-2, NANOG, NANOS, STELLA, CD9, LIN28, KLF4, GDF3, and $M Y C$, characteristic for pluripotent stem cells. The results of this study confirmed the presence of putative stem cells in the ovarian surface epithelium of these patients and provided some basis to create a stem cell line in the future.
\end{abstract}

\section{Introduction}

Human ovarian surface epithelium cell culture systems were developed much earlier to study the biology of epithelial cells [1-3]. Human ovarian surface epithelium cell cultures have been set up mostly in order to study the anti-inflammatory and proliferative responses of ovarian surface epithelium cells $[4,5]$ and to elucidate the mechanisms of ovarian cancer formation [6-9]. During the last few years, there have also been more reports on the human ovarian surface epithelium stemness, that is, on the epithelial-mesenchymal transitions [10-12]. Gene expression profiling supported the hypothesis that human ovarian surface epithelia are multipotent and also capable of serving as ovarian cancer initiating cells. Bowen and his coworkers performed comparative gene expression profiling analyses on ovarian surface epithelium removed from the surface of normal human ovaries and ovarian cancer epithelial cells isolated by laser capture microdissection from human serous papillary ovarian adenocarcinomas [13]. The genes associated with adult stem cell maintenance and with a multipotent capacity were highly expressed in healthy ovarian surface epithelia and were not expressed or expressed at very low levels in adenocarcinoma [13]. Observations by Parrott and coworkers demonstrated the production and action of the kit ligand/stem cell factor by using normal human ovarian surface epithelial cells and ovarian cancer cells [14]. It was confirmed that normal ovarian surface epithelium expressed high levels of kit ligand in vitro and in vivo. Kit ligand was found to stimulate the growth of normal ovarian surface epithelial cells.

An aspect of normal ovarian surface epithelium function is regeneration and repeated cell proliferation after ovulations during the reproductive period of life. Ovarian surface epithelium has also been confirmed as a source of oocytes during the embryonic/fetal period of life in humans as based on microanatomical studies by electron microscopy [1517]. In a similar way as for fetal ovaries the adult ovarian 
surface epithelium has also been proposed as a source of oocytes early in the history of the reproductive physiology [18-21]. Some experimental evidence has been brought by Bukovsky and his co-workers who scraped the ovarian surface epithelium in postmenopausal women, set up a cell culture from the scrapings, and confirmed the presence of oocyte-like cells which developed in vitro [22]. They concluded that in the ovarian surface epithelium layer of human postmenopausal ovaries precursor pluripotent stem cells were present. Further, Virant-Klun and her co-workers confirmed small round cells in the ovarian surface epithelium layer of women with no naturally present follicles and oocytes, which were positive for some pluripotent embryonic stem cell markers and differentiated in vitro into oocytelike cells and parthenogenetic blastocyst-like structures [2325]. Recently, these results have been confirmed in the adult ovarian surface epithelium of human and other mammalian species by Parte and co-workers [26].

The aim of this study was to explore further the putative stem cells in the ovarian surface epithelium of patients with premature ovarian failure. In the majority of these patients the underlying cause of premature ovarian failure had not been identified. The known causes are genetic aberrations, ovarian damage due to autoimmune disorders (i.e., antiovarian antibodies), iatrogenic disturbances due to surgical, radiotherapeutic or chemotherapeutic interventions in cancer patients, and environmental factors such as viral infections and toxins [27]. Recently, some studies have also confirmed that the inhibition of the enzyme telomerase and the shortening of telomeres can be seen in patients with ovarian insufficiency [28]. In the field of reproductive medicine, infertile patients with nonfunctional ovaries are of interest, and any potential to regenerate their ovaries would be of great importance.

\section{Materials and Methods}

In this study, 3 patients with premature ovarian failure aged 21,30, and 42 years were included after their written consent. They were all characterized by amenorrhea before the age of 40, high serum FSH and LH levels, and with no naturally present follicles or oocytes, except primordial follicles in the first patient. This study was confirmed by the Slovenian Medical Ethical Committee (Ministry of Health, no. 110/10/05).

In each patient, a routine laparoscopic ovarian cortex biopsy with a volume of app. $0.3 \mathrm{~cm}^{3}$ was performed to evaluate their potential fertility status. As in everyday medical practice, a part of the retrieved ovarian tissue was sent to the Service of Histopathology in our department to evaluate the potential presence of follicles or oocytes after haematoxylineosin staining. Additionally, the ovarian cortex sections were stained with cytokeratin to evaluate the presence and morphology of the ovarian surface epithelium.

Another part of the ovarian tissue was used to set up a cell culture. The tissue was carefully rinsed using a sterile physiologic solution to remove as many blood cells as possible. It was put on a wet and sterile gauze and transferred to the lab as soon as possible. In the lab it was placed in $2.5 \mathrm{~mL}$ of preincubated DMEM/F-12 culture medium in a small Petri dish and the ovarian surface epithelium was scraped using a sterile blade (Romed, Netherland) in a flow hood. The scraped population of cells was used for research. Droplets of the scraped population of cells were carefully monitored under the heat-staged inverted microscope (Nikon ECLIPSE TE2000-S, Japan) equipped with the Nikon Digital Sight DS-Ril camera at 200/400-times magnification (Hoffmann illumination) and 6,000-times magnification (immersion objective, dicNomarski illumination) to find some cells of unknown origin among the epithelial and blood cells. Putative stem cells were supposed to be completely round and with the nuclei filling almost the whole cell volumes. Drops of scraped cells were also stained with DAPI to evaluate the nuclei of the cells, immunocytochemically on the expression of SOX-2, as a marker of pluripotency, and by May-Grünwald-Giemsa staining to evaluate the presence of blood cells. In each patient, the ovarian surface epithelium cell culture was set up in a culture medium with added heterologous follicular fluid from the in vitro fertilization program to provide some kind of ovarian niche to the cells developing in vitro. The development of cell clusters or the presence of single cells positive on the expression of markers of pluripotency, such as surface antigen SSEA-4, nuclear marker SOX-2, and alkaline phosphatase activity was evaluated. At the same time a human embryonic stem cell (frozen/thawed commercial line $\mathrm{H} 1,38$ th-40th passage) culture was established to be compared with the ovarian cell cultures.

2.1. Histological Analyses of Ovarian Tissue. A routine histology of ovarian tissue was performed on a part of the cortex tissue of each ovarian biopsy to evaluate the presence of follicles and oocytes in the ovarian cortex after haematoxylineosin staining. For the evaluation of ovarian surface epithelium, cytokeratin staining was performed (cytokeratins are proteins of keratin-containing intermediate filaments which are present in the intracytoplasmic cytoskeleton of epithelial tissue). The ovarian tissue was formalin-fixed, embedded in paraffin, and $10 \mu \mathrm{m}$ sections were collected on microscope slides. The sections were deparaffinized and rehydrated by the immersion of the slides in a $0.01 \mathrm{M}$ citrate buffer, $\mathrm{pH} 6.0$, at $98^{\circ} \mathrm{C}$ for 40 minutes. The slides were then cooled to room temperature, incubated for 20 minutes with a mouse monoclonal antibody against high molecular weight cytokeratin, clone 34ßE12 (Dako, Glostrup, Denmark) then diluted 1:200 in phosphate-buffered saline (PBS), washed, incubated with peroxidase-coupled rabbit anti-mouse immunoglobulins (Dako, Denmark), and peroxidase visualized using a diaminobenzidine solution as recommended by the vendor (Dako, Denmark). Finally, the slides were dehydrated and mounted in Canada balsam. The sections were evaluated under the light microscope at magnifications 200/400-times for the presence of ovarian surface epithelial cells exhibiting brown staining for cytokeratin.

2.2. DAPI Staining of Cells. To monitor the cell nuclei, a small drop of the cell population scraped from the 
ovarian surface epithelium was put in a drop of Vectashield mounting medium for fluorescence with the DAPI (Vector Laboratories) and observed under a fluorescent microscope (Nikon ECLIPSE E-600 with Nikon Digital Sight camera, magnifications 200/400-times) after 20 minutes of incubation at room temperature and in the dark. The cell nuclei were stained blue.

2.3. May-Grünwald-Giemsa Staining. To evaluate the blood cells in a scraped population of cells, smears of the cell suspension were fixed in absolute methanol for at least 30 seconds. The methanol was removed by removing the slide from the fixing jar. Then the filtered staining solution I $(0.3 \mathrm{~g}$ May-Grünwald powder in $100 \mathrm{~mL}$ absolute methanol left in a closed container at room temperature for 24 hours) freshly diluted with an equal part of buffer was applied for 5 minutes on a horizontally positioned slide in a jar. Then the slide was transferred from the jar without washing into the filtered staining solution II (1 g Giemsa stain powder dissolved in $66 \mathrm{~mL}$ glycerol and heated to $56^{\circ} \mathrm{C}$ for 90 minutes) that had been freshly diluted with 9 parts of buffer for 10 to 15 minutes. The slide was transferred to a jar with a fresh buffer for one rinse after removing the stain. Then the slide was washed with water for 5 minutes by transferring the slide to a jar with water. After washing, the slide was dried in a tilted position and mounted with a cover glass. The slide was not allowed to dry or evaporate between the steps to prevent staining the artifacts and precipitates. The slide was monitored under an inverted microscope (Hoffman illumination, magnification 200-times). The cell nuclei were stained blue.

2.4. Fluorescent Immunocytochemistry of the Scraped Cells on SOX-2 Expression. Cells scraped from the ovarian surface epithelium were fixed in $4 \%$ paraformaldehyde for 10 minutes and permeabilized with $0.2 \%$ Triton for 10 minutes at room temperature. After fixation and permeabilization, the cells were incubated for 20 minutes with $10 \%$ FBS to block the nonspecific binding sites. Then the cells were incubated for 1 hour with phycoerythrin (PE)-conjugated antibodies against SOX-2 (BD Pharmingen, 1:50) in the dark and at room temperature. After staining, the cells were washed with PBS and observed under a fluorescent microscope.

\subsection{Set up of the Ovarian Surface Epithelium Cell Culture.} The ovarian surface epithelium cell cultures were set up using scraped cells. In each patient, the cell culture was set up in four 4-well dishes. Each well was filled with $350 \mu \mathrm{L}$ of preincubated culture medium: Dulbecco's Modified Eagle's Medium (DMEM)/Nutrient Mixture F12 Ham with Lglutamine, phenol red and $15 \mathrm{mM}$ HEPES (Sigma), supplemented with $3.7 \mathrm{~g} / \mathrm{L} \mathrm{NaHCO}_{3}, 1 \%$ penicillin/streptomycin, $0.5 \%$ gentamycin, and the $\mathrm{pH}$ was adjusted to 7.4 with $1 \mathrm{MNaOH}$. To culture the scraped cells, a solution of DMEM/F-12 medium with $20 \%$ (v/v) of follicular fluid from the in vitro fertilization program was prepared. Follicular fluid was added to provide some ovarian niche to the cells developed in the culture and to trigger the differentiation of the putative pluripotent/multipotent stem cells into the oocyte direction. Into each well, 5 droplets of scraped cell suspension were added ( 1 droplet: app. $10 \mu \mathrm{L}$ ). The cells were cultured for 4 weeks in a $\mathrm{CO}_{2}$-incubator (Haereus, Germany) at $37^{\circ} \mathrm{C}$ and $6 \% \mathrm{CO}_{2}$ in air. The culture was monitored daily under the heat-staged inverted microscope equipped with the digital camera at 200/400/6,000-times magnification and followed on the potential development of the oocytelike cells and the cell clusters resembling those formed by human embryonic stem cells. At the same time, the human embryonic stem cell culture was established to be compared with the ovarian cell cultures; human embryonic stem cells were cultured in the culture medium for human embryonic stem cells and on a Matrigel (Invitrogen) as the feeder layer.

2.6. Follicular Fluid Retrieval. In the in vitro fertilization program, the follicular fluid retrieved at the oocyte aspiration and after a written consent was donated by a young patient with a normal ovarian reserve and normal response to the hormonal ovarian stimulation. Previous testing for HIV and hepatitis viruses revealed that she was healthy. The follicular fluid was used immediately after the removal of oocytes (to be fertilized in vitro) so as not to coagulate. To prepare the follicular fluid "serum," it was centrifugated for 10 minutes at $2,500 \mathrm{rpm}$. The supernatant was filtered through a sterile Sartorius Minisart $0.45 \mu \mathrm{m}$ filter to remove all possible cells (i.e., granulosa cells, theca cells, blood cells, and cells from the immunological system). The filtered supernatant was heat-inactivated at $56^{\circ} \mathrm{C}$ for 45 minutes. Then it was aliquoted and stored at $-20^{\circ} \mathrm{C}$ until use. When used, it was thawed at $37^{\circ} \mathrm{C}$ and a supplemented DMEM/F12 culture medium with $20 \%$ (v/v) of follicular fluid "serum" was prepared, as described above.

\subsection{Immunocytochemistry of Cells and Cell Clusters for} SSEA-4 and SOX-2 Expressions (ABC Method). The cells were fixed in $4 \%$ paraformaldehyde and permeabilized with $0.2 \%$ Triton (for SOX-2), incubated with $3 \% \mathrm{H}_{2} \mathrm{O}_{2}$ for 5 minutes to block the endogenous peroxidase activity and for 20 minutes with $10 \%$ FBS to block the non-specific binding sites. Then the cells were incubated with primary antibodies specific for SOX-2 (Abcam, 1:100) or SSEA4 (Millipore, $1: 100$ ) for 1.5 hours at room temperature. After washing with PBS, the cells were incubated with biotinylated secondary antibodies (Polyclonal Rabbit AntiMouse Immunoglobulins, DakoCytomation, 1:400) for 45 minutes and then with an $\mathrm{ABC}$ reagent (Vectastain Elite $A B C$ Kit) for 30 minutes. Finally, the cells were incubated in a DAB substrate (Sigma) for 5 minutes, washed with PBS, and observed under an inverted microscope (Hoffman illumination) to detect positive-brown stained cells or cell colonies. Human embryonic stem cells were used as a positive control. For a negative control, the primary antibodies were omitted from the procedure and replaced with 1\% FBS.

2.8. Alkaline Phosphatase Staining. An alkaline phosphatase detection kit (Millipore) was used for alkaline phosphatase 
(AP) staining for the presence of pluripotent or multipotent (mesenchymal) stem cells in the cell cultures. Briefly, the cells were fixed in $4 \%$ paraformaldehyde for 3 minutes, permeabilized with $0.2 \%$ Tween-20 for 10 minutes, and incubated for 30 minutes in a working solution of reagents, which consisted of Fast Red Violet, Naphthol AS-BI phosphate solution, and water in a $2: 1: 1$ ratio. The culture was observed under an inverted microscope (Hoffman illumination) to confirm AP activity. The cells or cell colonies expressing AP activity were stained from pink to a red color. Human embryonic stem cells were used as a positive control.

2.9. Single-Cell Gene Expression Analyses by Fluidigm BioMark System. Gene expression analyses of 11 single oocyte-like cells developed in vitro in one patient with no naturally present follicles or oocytes in comparison with single hESCs, groups of 5, 10, 20 hESCs ( $\mathrm{H} 1$ line; positive controls) and single human fibroblasts, groups of 5, 10, 20 fibroblasts (F161; negative controls) were performed using the Biomark Real-Time quantitative PCR (qPCR) system (Fluidigm). Each oocyte-like cell was mechanically removed from the cell culture by a glass pipette (Swemed, denudation pipette, 0.134-0.145 mm), and expressions of 11 genes, characteristic for pluripotent stem cells: STELLA, OCT4A, LIN28, GDF3, NANOG, MYC, KLF4, SOX-2, TERT, CD9, NANOS, and of the housekeeping gene GAPDH were analyzed. The inventoried TaqMan assays (12x, Applied Biosystem) were pooled to a final concentration of $0.2 \mathrm{x}$ for each of the 12 assays. Cells to be analyzed were harvested directly into $9 \mu \mathrm{L}$ RT-PreAmp Master Mix (5.0 $\mu \mathrm{L}$ CellsDirect 2x Reaction Mix (Invitrogen); $2.5 \mu \mathrm{L} 0.2 \mathrm{x}$ assay pool; $0.2 \mu \mathrm{L}$ RT/Taq Superscript III [Invitrogen]; $1.3 \mu \mathrm{L}$ TE buffer). The harvested cells were immediately frozen and stored at $-80^{\circ} \mathrm{C}$. Cell lysis and sequence-specific reverse transcription were performed at $50^{\circ} \mathrm{C}$ for $15 \mathrm{~min}$. The reverse transcriptase was inactivated by heating to $95^{\circ} \mathrm{C}$ for $2 \mathrm{~min}$. Subsequently, in the same tube, cDNA went through limited sequence-specific amplification by denaturing at $95^{\circ} \mathrm{C}$ for $15 \mathrm{~s}$ and annealing and amplification at $60^{\circ} \mathrm{C}$ for $4 \mathrm{~min}$ for 14 cycles. These preamplified products were diluted 5 -fold prior to analysis with Universal PCR Master Mix and inventoried TaqMan gene expression assays (ABI) in 96.96 Dynamic Arrays on a BioMark System. Each sample was analyzed in two technical replicates.

Ct values obtained from the BioMark System were transferred to the GenEx software (MultiD) to analyze gene expressions. Missing data in the Biomark system were given a Ct of 999. These were removed in GenEx. Also Ct's larger than 25 were removed (cutoff value more than 25), since samples with such high Ct's in the Biomark $96 \times$ 96 microfluidic card were expected to be negative and these readings were unreliable. Technical repeats were then averaged. Missing data were then replaced by the highest $\mathrm{Cq}+1$ for each gene. This corresponded to assigning a concentration to these samples that was half of the lowest concentration measured and was motivated by sampling ambiguity. There was also need to handle missing data for downstream classification with multivariate tools. Linear quantities were calculated relative to the sample having lowest expression and data were converted to $\log _{2}$ scale. The data were now prepared for multivariate analysis to classify the samples based on the combined expression of all the genes. Heatmap, corresponding hierarchical clustering (Ward's Algorithm, Euclidean Distance Measure) and principal component analysis (PCA) were performed. Groups of cells-oocyte-like cells (OLCs), hESCs, fibroblastswere compared using unpaired 2-tailed Student's T-Test. Statistical significance was set at $P<0.00465$ (DunnBonferroni correction) to account for false positives due to multiple testing.

\section{Results and Discussion}

As can be seen from Figure 1, immunohistochemistry confirmed the severe premature ovarian failure in all patients. In the first patient, haematoxylin-eosin staining of the ovarian cortex sections revealed some primordial follicles in the ovarian cortex (Figures 1(a)-1(d)), whereas in both other patients there were no follicles or oocytes in the ovarian cortex (Figures 1(e)-1(h)). In all patients, the cytokeratin staining confirmed the presence of ovarian surface epithelium at the ovarian surface. In the first patient cells forming primordial follicles also positively stained on cytokeratin. It is known that in the human fetal ovaries, sex cords also give rise to cytokeratin positive cells in primordial follicles [29]. In adult human ovaries, Löffler and co-workers found that cytokeratin-positive follicular or granulosa cells were present in the primordial and primary follicles as well as in the preovulatory follicles, whereas they were not detected in the granulosa cells of growing follicles. They concluded that the heterogeneous morphology of the granulosa cells in adult human ovaries may be explained by their twofold origin from the surface epithelium and the rete thus reflecting cytokeratin positivity or negativity [30]. The cytokeratin positive cells might represent immune-like granulosa cells involved in ovarian remodeling processes [31] or related to follicular atresia or cystic ovarian disease, as revealed in the animal model [32].

In all 3 patients with POF, small round cells of yellow color and with diameters of 2 to $4 \mu \mathrm{m}$ were found as captured among epithelial cells in ovarian surface epithelium scrapings (Figure 2). Ovarian surface epithelium scrapings did not only consist of epithelial cells but also from small round cells with diameters of 2 to $4 \mu \mathrm{m}$ which were captured among the epithelial cells or were attached to them (Figures $3(\mathrm{a})-3(\mathrm{~d}))$. These small round cells did not originate from the blood stream but were an integral part of the ovarian surface epithelium. In a scraped population of cells there were similar small round cells with diameters of 2 to $4 \mu \mathrm{m}$ (Figure 3(e)). These cells appeared among the epithelial cells and blood cells (mostly erythrocytes).

The small round cells scraped from the ovarian surface epithelium had completely round nuclei which filled almost the entire cell volumes, as revealed using DAPI staining (Figures 4(a)-4(d)). After May-Grünwald-Giemsa staining, small round cells with diameters of 2 to $4 \mu \mathrm{m}$ scraped from 


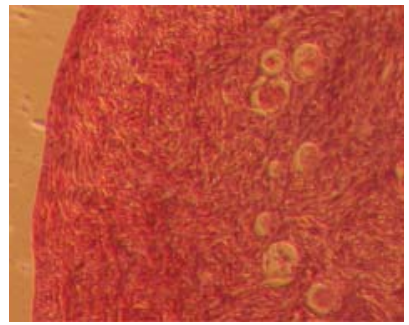

(a)

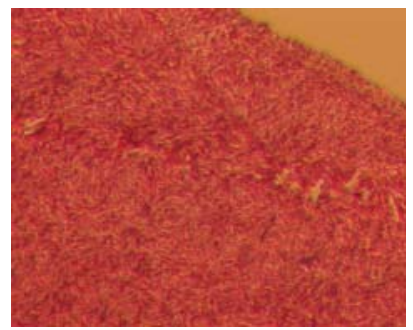

(e)

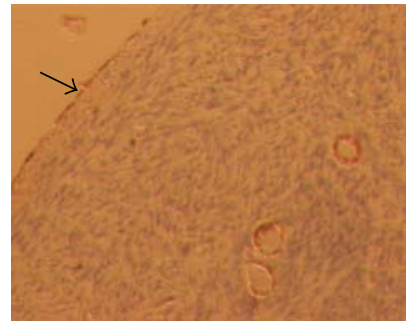

(b)

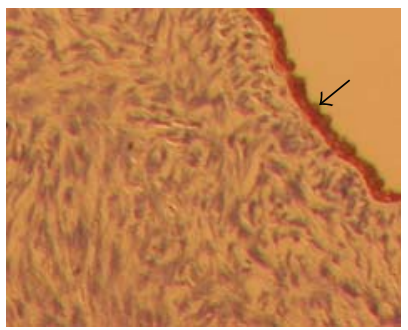

(f)

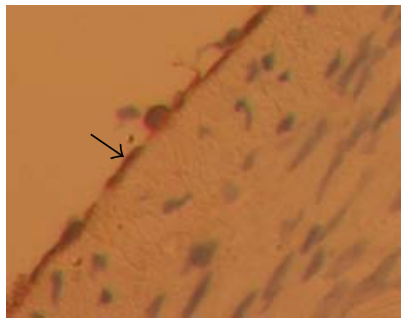

(c)

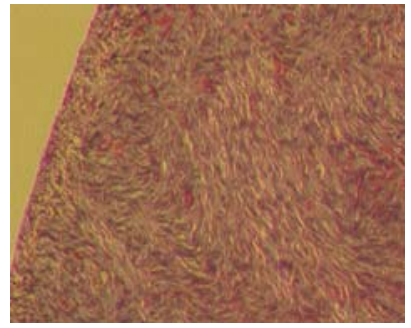

(g)

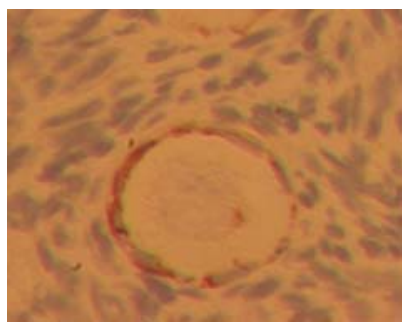

(d)

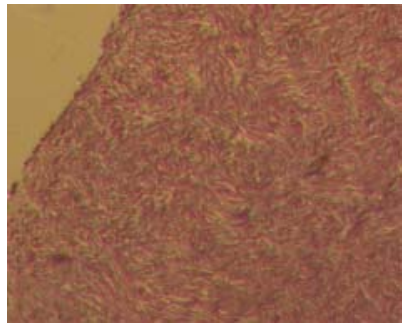

(h)

FIGURE 1: Histology of ovarian cortex sections in patients. (a) Ovarian cortex with primordial follicles after haematoxylin-eosin staining in the first patient (magnification 100-times). (b-d) Ovarian surface epithelium (arrow) and primordial follicles positively (brown) stained on cytokeratin in the first patient (magnifications 100-times and 200-times). (e, f) Fibrous ovarian cortex without follicles after haematoxylineosin staining and ovarian surface epithelium (arrow) positively (brown) stained on cytokeratin in the second patient (magnification 100times). (g, h) Fibrous ovarian cortex without follicles after haematoxylin-eosin staining in the third patient (magnification 100-times). (Light microscope.)

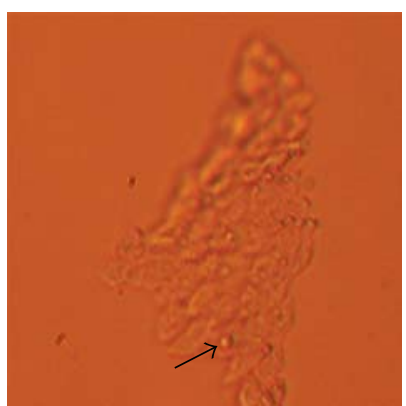

(a)

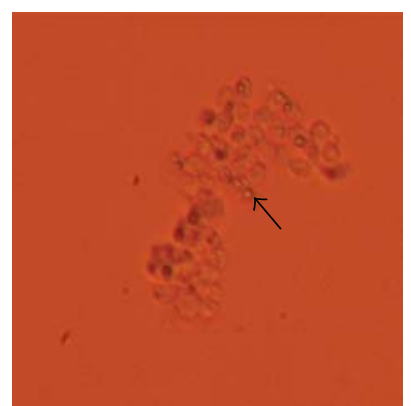

(b)

Figure 2: Small round cells (arrows)—putative stem cells with diameters of 2 to $4 \mu \mathrm{m}$ in the ovarian surface epithelium scrapings. (a, b) Among the epithelial cells. (Inverted microscope, Hoffman illumination, magnifications 100 and 200-times.)

the ovarian surface epithelium did not stain or were weakly stained (Figure 4(e)). All blood cells, including lymphocytes, nicely stained blue (Figure 4(f)). Similarly, this has been observed by Parte and co-workers who experienced difficult DAPI staining of comparable small round cells scraped from the human adult ovarian surface epithelium; they explained that these cells might have a highly compacted nuclear chromatin which impeded staining [26]. In our study, erythrocytes were the predominating blood cells in a population of cells scraped from the ovarian stem cells, and small round cells were significantly lower than the erythrocytes. Other types of blood cells represented about $1 \%$ of all scraped cells, as revealed by May-Grünwald-Giemsa staining. Small round cells could be comparable to lymphocytes due to their round shape and high nuclear/cytoplasm ratio, but were significantly smaller. The lymphocytes were slightly bigger than the erythrocytes and strongly stained using MayGrünwald-Giemsa, while the small round cells did not stain or weakly stained (Figures 4(e), and 4(f)).

After immunocytochemical staining in our study, a proportion of small round cells positively stained on SOX2, a marker of pluripotency just after the scraping (Figure 5). These results confirmed our previous observations of putative stem cells in the adult human ovarian surface epithelium [23-25] and recent observations of Parte et al. [26]. These cells could be quite comparable to very small embryonic-like stem cells (VSELs) found in other adult human tissues and organs (i.e., bone marrow) by the group of Ratajczak [3335 ] and differentiated into different types of cells, that is, cardiomyocytes [36]. Experimental data showed that VSELs 


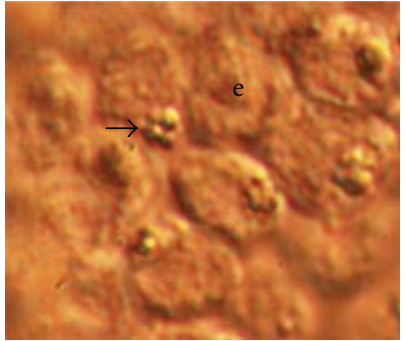

(a)

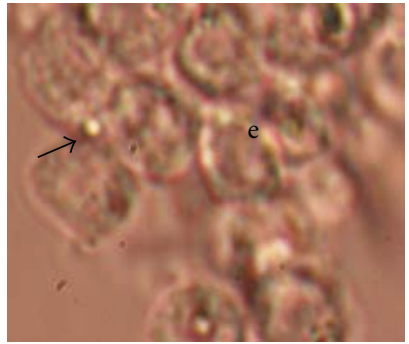

(b)

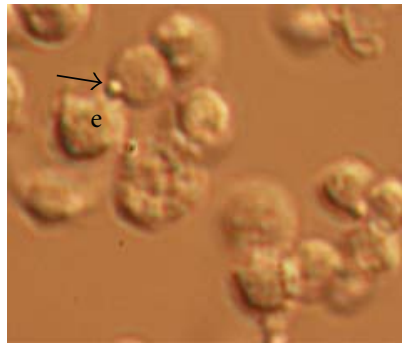

(c)

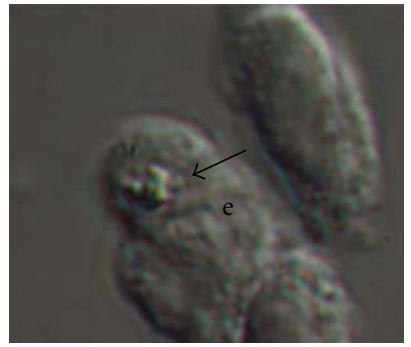

(d)

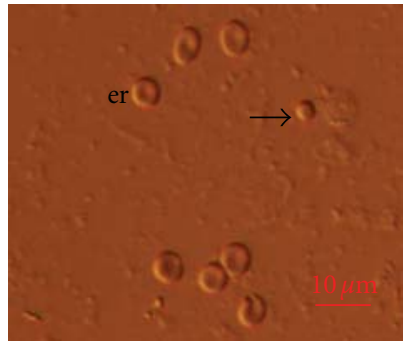

(e)

Figure 3: Small round cells (arrows)—putative stem cells in the ovarian surface epithelium. (a-d) Among the epithelial cells in the ovarian surface epithelium scrapings (magnification 6,000-times). (e) Among the erythrocytes in a scraped population of cells (magnification 200times). (Inverted microscope, dic-Nomarski illumination, immersion objective for magnification 6,000-times, and Hoffman illumination for magnification 200-times.) e: epithelial cells, er: erythrocytes.

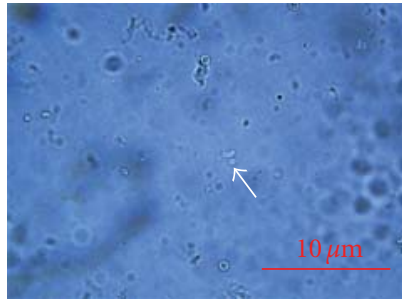

(a)

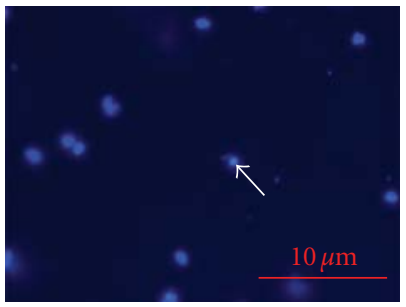

(b)

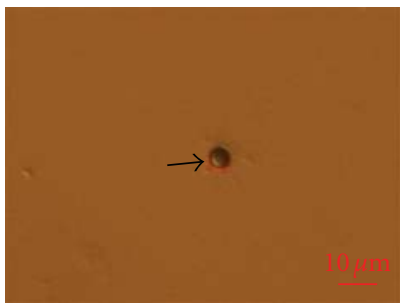

(e)

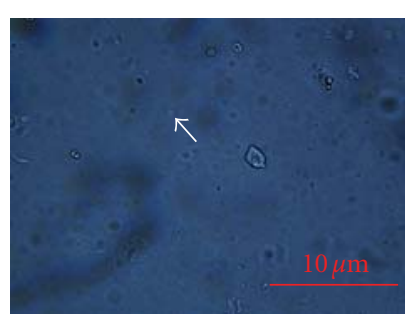

(c)

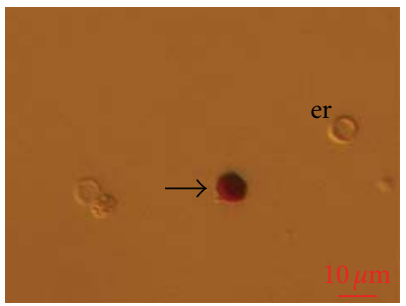

(f)

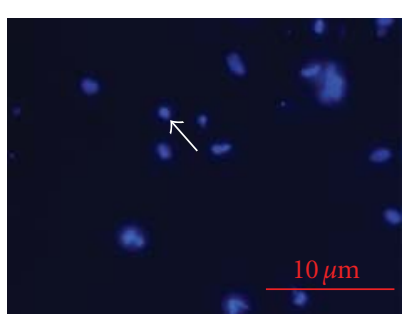

(d)

FIGURE 4: Small round cells (arrows)_-putative stem cells in a population of cells scraped from the ovarian surface epithelium. (a) Just after scraping (magnification 100-times). (b) After DAPI staining (magnification 100-times). (c) Just after scraping (magnification 100-times). (d) After DAPI staining (magnification 100-times). (e) Weakly-stained small round cell-putative stem cell after Giemsa staining (magnification 200-times). (f) Blue-stained lymphocyte (arrow) after Giemsa staining (magnification 200-times). (Light, fluorescent, inverted microscopes.)

may originate from epiblast/migrating primordial germ celllike cells and, in spite of the expression of pluripotent stem cell markers, the changed epigenetic regulation of the imprinted genes keep these cells silent in adult tissues and prevent teratoma formation [37]. The small round cells we found in this study are therefore proposed as very small embryonic-like stem cells in the ovarian surface epithelium of patients with premature ovarian failure.

After 4 days of culture some bigger round cells with diameters of up to $20 \mu \mathrm{m}$ developed in the ovarian surface epithelium cell cultures of all patients. These cells were not present in the scraped population of cells, and they developed 


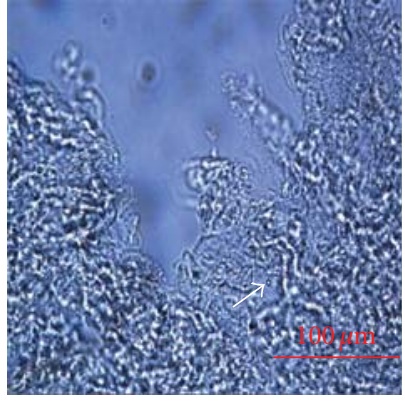

(a)

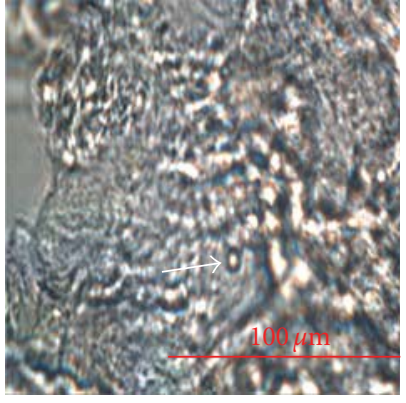

(b)

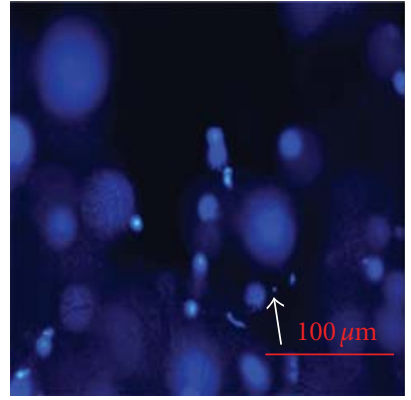

(c)

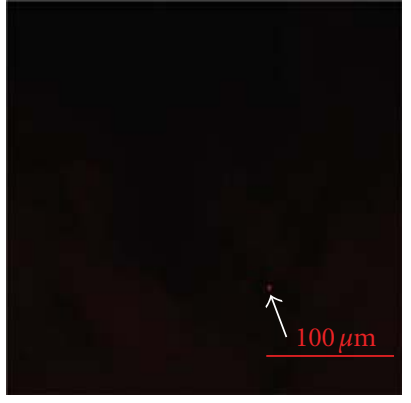

(d)

Figure 5: Small round cells (arrows)-putative stem cells in a population of cells scraped from the ovarian surface epithelium. (a) Just after scraping (magnification 400-times). (b) Just after scraping (magnification 1,000-times). (c) After DAPI staining (magnification 400-times). (d) Positively (red) stained on the SOX-2 marker of pluripotency (magnification 400-times). (Light and fluorescent microscope.)

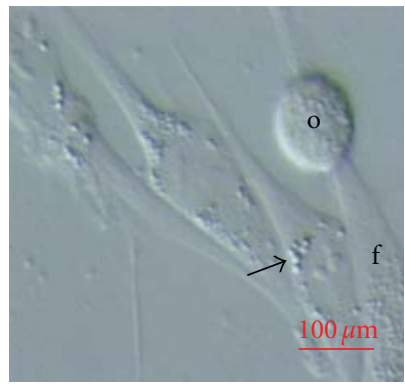

(a)

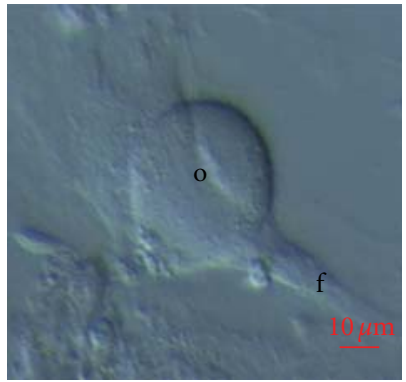

(b)

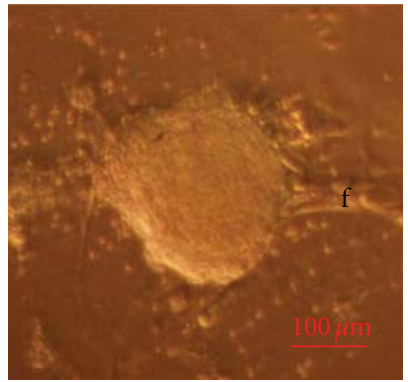

(c)

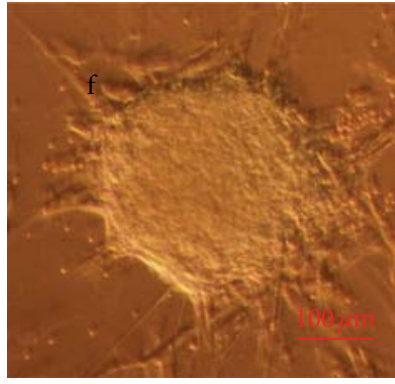

(d)

FIGURE 6: In vitro culture of cells scraped from the ovarian surface epithelium. (a) Oocyte-like cell developed in vitro on autologous ovarian fibroblasts and small round cells (arrow) with diameters of 2 to $4 \mu \mathrm{m}$ proliferating in the surroundings as attached to fibroblasts on day 4 of the culture (magnification 100-times). (b) Oocyte-like cell developed in vitro on autologous ovarian fibroblasts on day 10 of the culture (magnification 200-times). (c, d) Cell clusters developed in vitro on autologous ovarian fibroblasts on day 4 of the culture (magnification 100-times). (Inverted microscope, Hoffman illumination.) f: autologous ovarian fibroblast, o: oocyte-like cell.

in vitro. They were mostly attached to the autologous ovarian fibroblasts in the cultures (Figure 6(a)). Fibroblasts might provide them some substances, which were important for their growth and development, that is, fibroblast growth factor-2 (FGF-2). This was similar to human embryonic stem cells which can successfully proliferate and grow only on the fibroblast (or other) feeder layer to provide them FGF-2 (and other substances) and to maintain their nondifferentiated state [38]. Fibroblasts also possess aromatase which catalyzes the conversion of $\mathrm{C}(19)$ steroids into estrogens, important for oocyte development [39]. Surrounding some of these bigger round cells, small round cells with diameters of 2 to $4 \mu \mathrm{m}$ and of unknown origin were present and were similarly attached to the autologous fibroblasts in the culture (Figure 6(a)). These small round cells were similar to those present among the epithelial cells just after the ovarian surface epithelium scraping. It is not excluded that bigger round cells developed in vitro from smaller ones. After 10 days of culture, some bigger round cells reached a diameter of up to $60 \mu \mathrm{m}$ (Figure 6(b)). These cells resembled primitive oocytes, but were much smaller (average diameter of human oocytes is more than $100 \mu \mathrm{m}$ ) and did not develop zona pellucida-like structures, characteristic for oocytes. The development and growth of these bigger round cells was induced by heterologous follicular fluid serum rich in substances needed for oocyte growth and development. Follicular fluid has already been used for in vitro maturation of human oocytes in the in vitro fertilization program [40]. Follicular fluid contains high levels of hormones-estrogens, progesterone, FSH, and androgens [41], proteins [42], amino acids [42], a high concentration of lipids, free cholesterol and meiosis-activating sterol (FF-MAS) [40, 43], growth factors [44], and other substances, and therefore might "push" the development of stem cells in the direction of primitive oocytes.

After 4 days of culture, round-shaped cell clusters with clearly distinguished margins also appeared in the cultures of all patients (Figures 6(c) and 6(d)). These cell clusters were abundant and relatively small. They were attached to the dish bottom and were spontaneously developed on autologous ovarian fibroblasts, similar to human embryonic stem cells which need fibroblasts or other feeder layers to proliferate and form cell clusters in vitro. Similar ovarian cell clusters were appearing all the time during the culture, and the old ones did not show any signs of degeneration. More cell clusters reached diameters larger than $100 \mu \mathrm{m}$.

After alkaline phosphatase staining, some of the cell clusters did not positively stain on alkaline phosphatase 


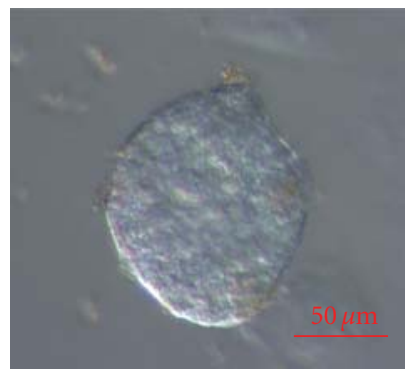

(a)

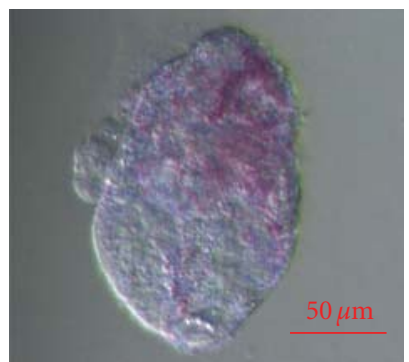

(e)

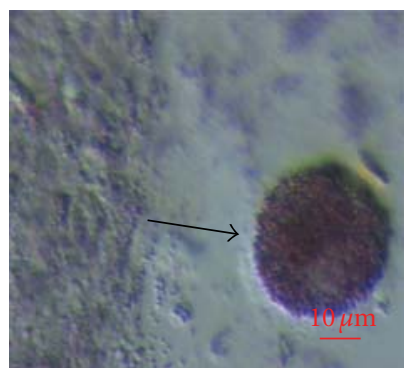

(b)

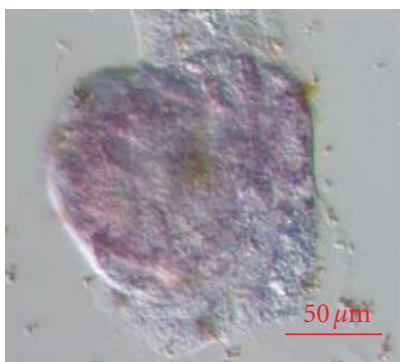

(f)

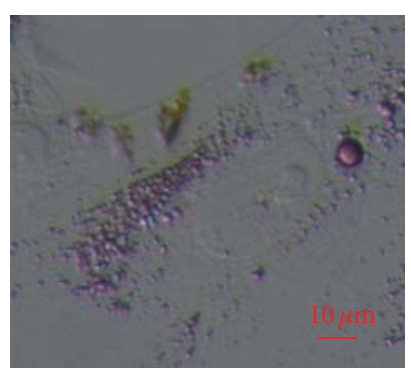

(c)

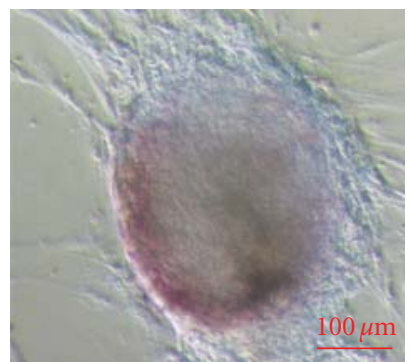

(g)

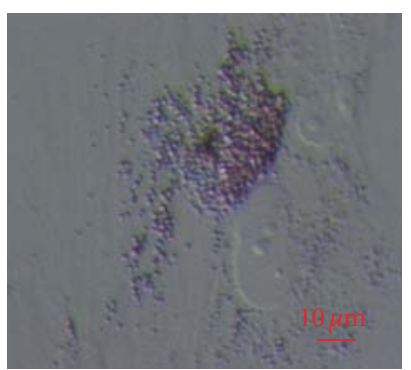

(d)

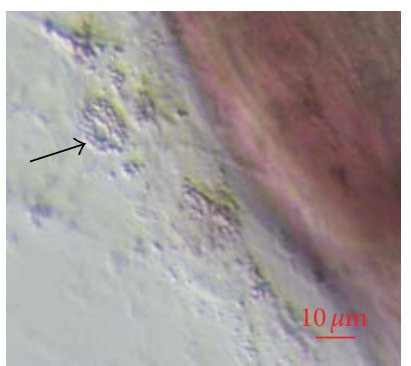

(h)

FIGURE 7: Alkaline phosphatase staining of cells and cell clusters during the culture of cells scraped from the ovarian surface epithelium. (a) Nonstained cell cluster (magnification 40-times). (b) Positively stained oocyte-like cell (arrow) (magnification 200-times). (c, d) Positively stained small round cells with diameters of 2 to $4 \mu \mathrm{m}$ proliferating in a cell culture (magnification 200-times). (e, f) Positively stained cell clusters (magnification 40-times). (g) Positively stained cell cluster developing on the layer of autologous ovarian fibroblasts (magnification 100-times). (h) Small round cells (arrow) with diameters of 2 to $4 \mu \mathrm{m}$ proliferating in the near surroundings (magnification 200-times). (inverted microscope, Hoffman illumination.)

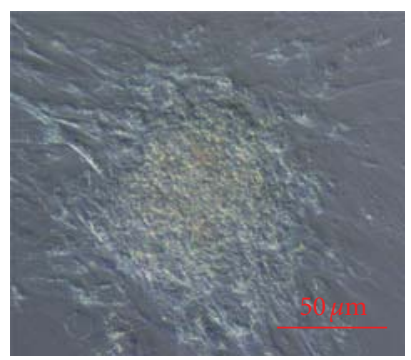

(a)

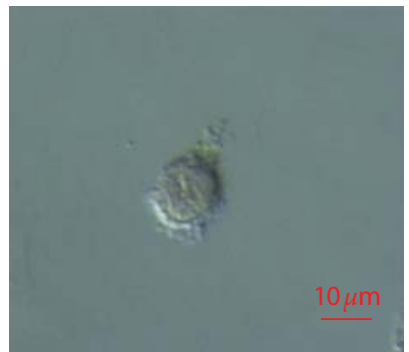

(e)

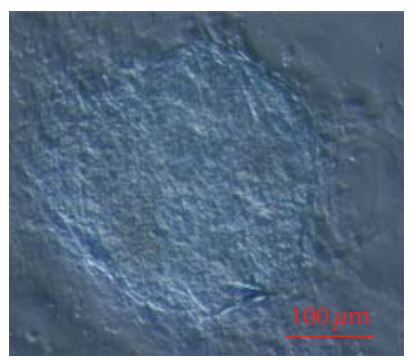

(b)

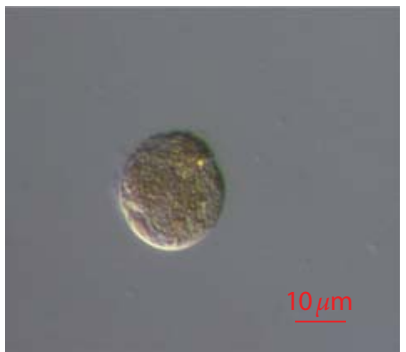

(f)

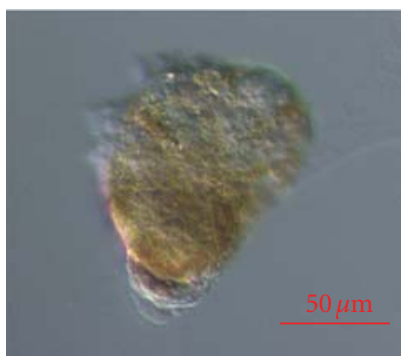

(c)

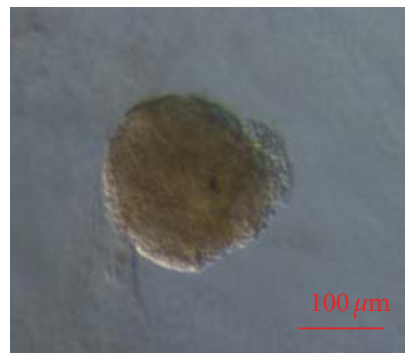

(g)

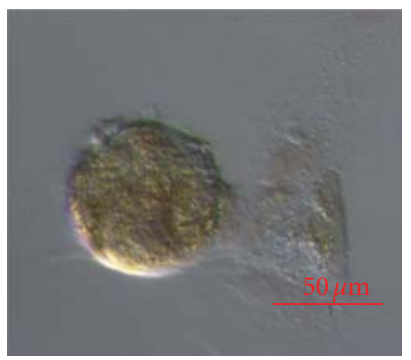

(d)

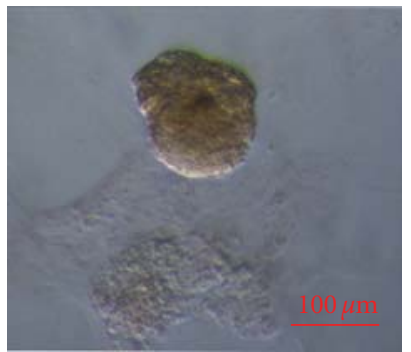

(h)

FIGURE 8: Immunocytochemical staining of cell clusters and oocyte-like cells developed during the in vitro culture of cells scraped from the ovarian surface epithelium on markers of pluripotency SOX-2 and SSEA-4. (a, b) Non-stained cell clusters (negative control) (magnifications 40-times and 100-times). (c, d). Cell clusters positively (brown) stained on SOX-2 (magnification 40-times). (e) SOX-2 non-stained round cell (negative control) (magnification 200-times). (f) Round cell positively (brown) stained on SOX-2 (magnification 200-times). (g, h) Cell clusters positively (brown) stained on SSEA-4 surface antigen (magnification 100-times). (Inverted microscope, Hoffman illumination.) 


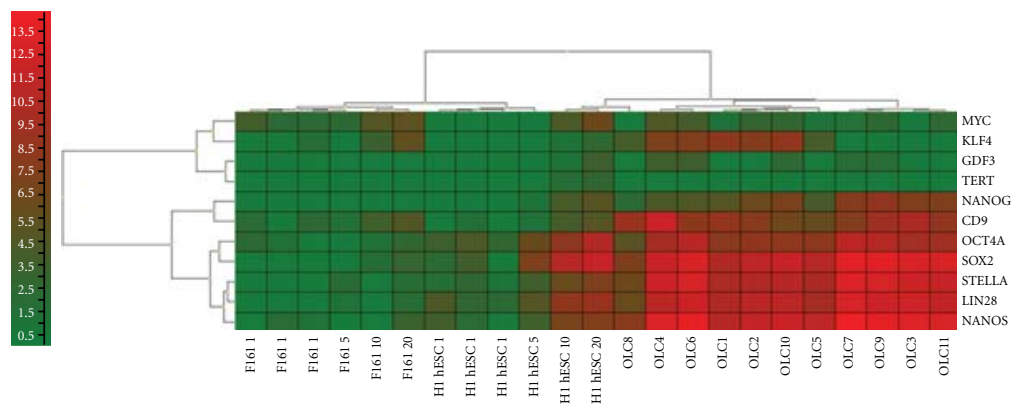

(a)

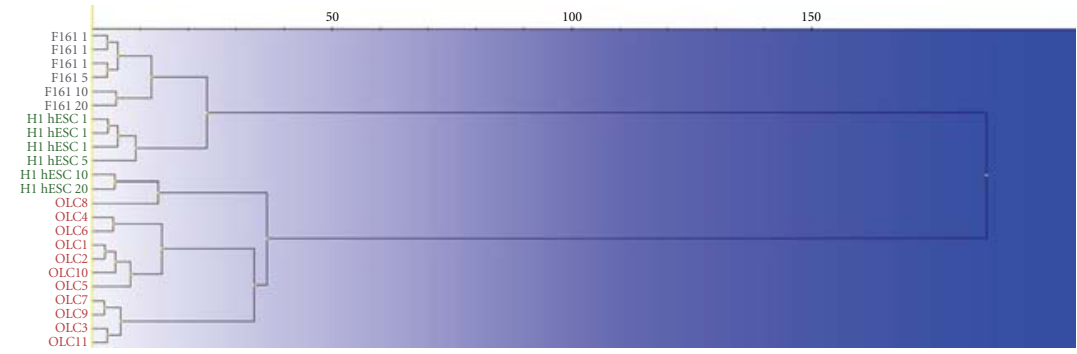

(b)

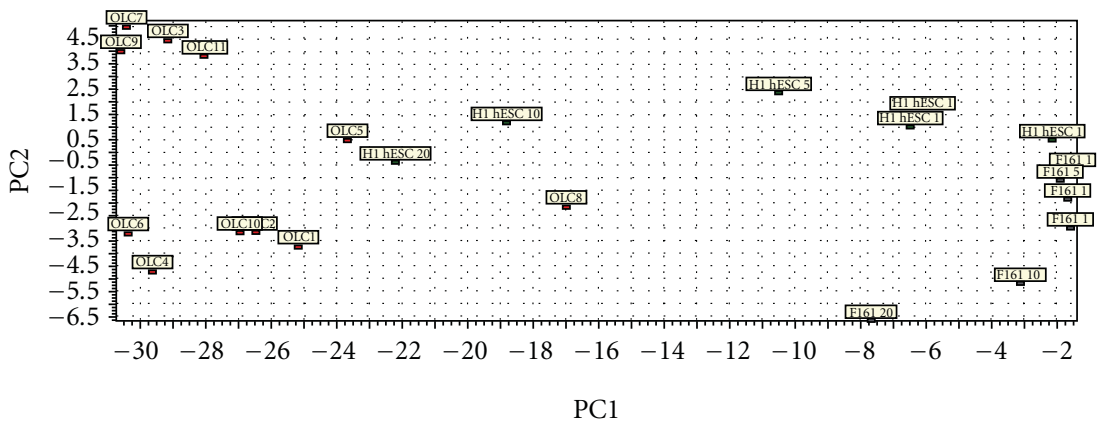

(c)

FIGURE 9: Single-oocyte-like cell gene expression analyses in comparison with human embryonic stem cells and human fibroblasts. (a) Heatmap clustering. (b) Hierarchical clustering (Ward's Algorithm, Euclidean Distance Measure). (c). Principal component analysis (PCA). Legend: OLC: single oocyte-like cells, H1 hESC: human embryonic stem cells (H1 cell line), F161: human fibroblasts (F161 cell line), 1: single cell, 5: group of five cells, 10: group of ten cells, and 20: group of twenty cells.

(Figure $7(\mathrm{a})$ ) but most of them did (Figures $7(\mathrm{e})-7(\mathrm{~h})$ ). Some bigger round cells positively stained (Figure $7(\mathrm{~b})$ ). In cultures, also some smaller round cells with diameters of 2 to $4 \mu \mathrm{m}$ were positively stained on alkaline phosphatase activity (Figures $7(\mathrm{c})$ and $7(\mathrm{~d})$ ). Most of the positively stained cell clusters were stained in some parts, but rarely the whole clusters were positively stained thus reflecting the fact that cell clusters were possibly composed of different types of cells, including a proportion of cells with a pluripotent/multipotent character. Around some positively stained cell clusters (Figure $7(\mathrm{~g})$ ) small round cells were present (Figure $7(\mathrm{~h})$ ). Single cells or cell clusters were positively stained on the alkaline phosphatase early, on day 6 of the culture, and also later, on day 20 of the culture.

Many cell clusters (Figures 8(c), 8(d), 8(g), and 8(h)) and bigger round cells resembling primitive oocytes (Figure $8(\mathrm{f})$ ) positively stained for markers of pluripotency SOX-2 and SSEA-4, as revealed by immunocytochemistry. Similar to those in the alkaline phosphatase, only some parts of the cell clusters were positively stained on SOX-2 and SSEA-4. This might reflect the fact that ovarian cell clusters were composed of different types of cells, including a proportion of stem cells. Ovarian cell clusters or single cells were positively stained early, on day 7 of the culture and also later, on day 30 of the culture. Analyzed cell clusters did not show any signs of degeneration or differentiation at the time of immunocytochemistry.

Single oocyte-like cells developed in vitro expressed most of analyzed genes, characteristic for pluripotent stem cells (STELLA, OCT4A, LIN28, GDF3, NANOG, MYC, KLF4, SOX-2, CD9, NANOS), except TERT, whereas hESCs expressed all analyzed genes of pluripotency (Figure 9(a)). Oocyte-like cells were relatively big cells, which strongly expressed genes of pluripotency. They expressed genes STELLA $\left(P=4.701 \times 10^{-6}\right), \operatorname{LIN} 28(P=0.000127455)$, NANOG $(P=0.001412627)$, SOX-2 $(P=0.002365882)$, 


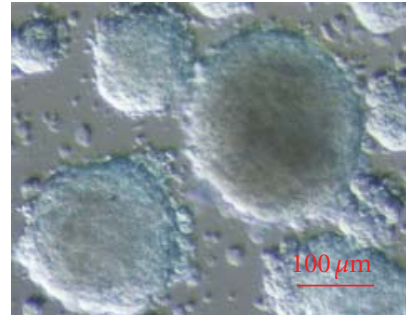

(a)

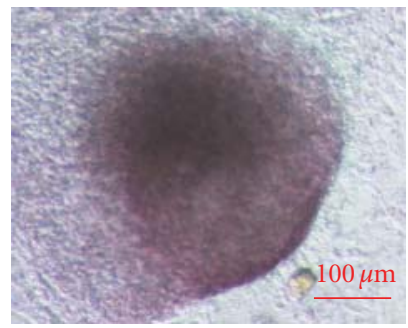

(e)

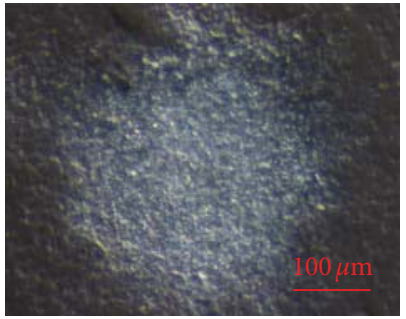

(b)

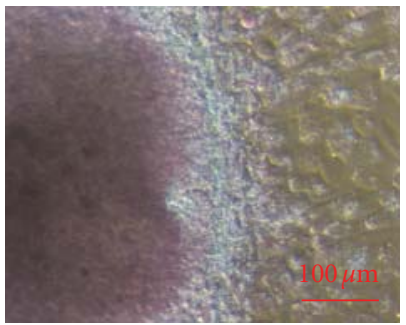

(f)

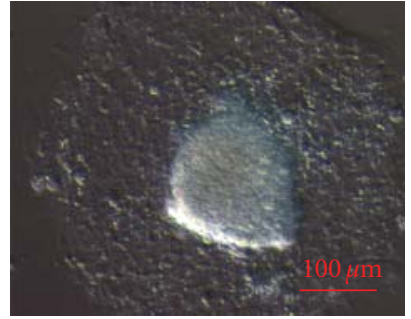

(c)

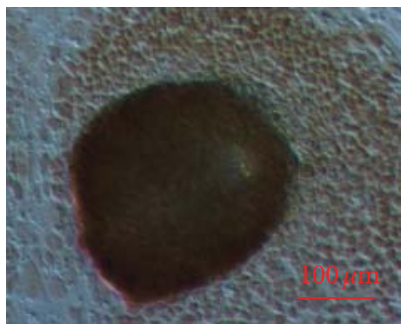

(g)

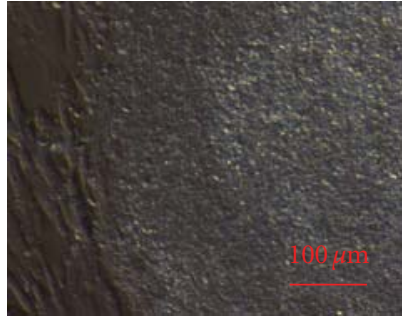

(d)

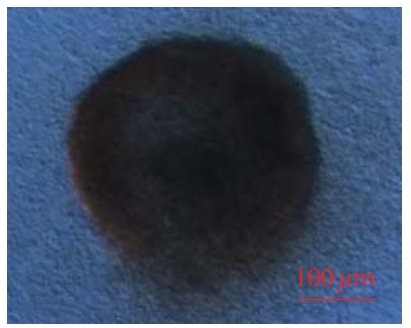

(h)

Figure 10: Cell culture of human embryonic stem cells as positive control. (a,b) Early cell clusters (magnification 100-times). (c) Developing cell cluster (magnification 100-times). (d) Developed cell cluster (magnification 100-times). (e,f) Cell clusters positively stained on alkaline phosphatase activity (magnification 100-times). (g) Cell cluster surrounded by small cells positively (brown) stained on the SOX-2 marker of pluripotency (magnification 100-times). (h) Cell cluster positively (brown) stained on surface antigen SSEA-4 characteristic for pluripotent stem cells (magnification 100-times). (Inverted microscope, Hoffman illumination.)

CD9 $\left(P=3.136 \times 10^{-6}\right)$, and $\operatorname{NANOS}\left(P=1.965 \times 10^{-6}\right)$ to significantly higher extent than hESCs, as revealed by Student's T-test. Human fibroblasts did not express genes of pluripotency (GDF3, NANOG, TERT) or expressed them to very low extent (Figure 9(a)). Comparing with oocyte-like cells they underexpressed genes STELLA $\left(P=1 \times 10^{-8}\right)$, OCT4A $\left(P=7.200 \times 10^{-8}\right), \operatorname{LIN} 28\left(P=1 \times 10^{-8}\right)$, SOX-2 $\left(P=1 \times 10^{-8}\right)$, CD9 $\left(P=2.815 \times 10^{-6}\right)$, and NANOS $\left(P=1 \times 10^{-8}\right)$. Single oocyte-like cells clustered together with groups of 10 and 20 hESCs, while single hESCs and a group of 5 hESCs clustered together with human fibroblasts and represented another group of cells because of low expression of analyzed genes, as revealed by heatmap clustering (Figure 9(a)), corresponding hierarchical clustering (Figure 9(b)), and principal component analysis (Figure 9(c)). Oocyte-like cells were cells expressing analyzed genes of pluripotency and not fibroblasts, as proposed for human adult germline stem cells $[45,46]$. They might be ovarian stem cells growing in the presence of donated follicular fluid, including different triggers of oocyte growth and maturation.

All the results in this study-the presence of small putative stem cells among epithelial cells, SOX-2-positive small cells just after the scraping, and alkaline phosphatase, SOX-2 and SSEA-4-positivity of cell clusters cultured in vitro-confirmed that in the adult ovarian surface epithelium of patients with premature ovarian failure there were naturally present stem cells which expressed some markers of pluripotency just after the ovarian surface epithelium scraping and also during the prolonged culture in vitro.

When we compared the morphology of the cell clusters developed in the cultures of cells scraped from the ovarian surface epithelium to human embryonic stem cells (Figure 10) cultured at the same time, we found that they could be quite comparable to the early cell clusters formed from the human embryonic stem cells (Figures 10(a) and 10(b)). Similar to the ovarian cell clusters, the cell clusters formed from the human embryonic stem cells were not homogenously positively stained on alkaline phosphatase, but only partially (Figures 10(e) and 10(f)). On the other hand, the whole cell clusters developed from human embryonic stem cells were positively stained on SOX-2 (Figure 10(g)) and SSEA4 markers of pluripotency (Figure $10(\mathrm{~h})$ ), thus confirming the fact that possibly they only consisted of pluripotent stem cells.

\section{Conclusions}

We can conclude that naturally present stem cells from the ovarian surface epithelium of patients with premature ovarian failure expressed some markers of pluripotency just after the scraping and during the culture in vitro. These cells did not originate from the blood stream but were an integral part of the ovarian surface epithelium, as observed in the scrapings. In spite of their specificity in terms of the morphology and dimensions, further research of the character of these cells is needed to elucidate if these are really embryonic-like stem cells expressing markers or pluripotency, or something else. They appeared to be comparable to very small embryonic-like cells found in other adult human tissues [33-36]. There have also been more reports about potential epithelial-mesenchymal transitions of the human ovarian surface epithelium [10-12] and 
about the expression of some markers of pluripotency in mesenchymal stem cells [47-49] from other human tissues; therefore ovarian stem cells need to be critically researched in the future in terms of their character. Our results showed the possibility of creating human ovarian stem cell lines, like in the previous reports in the mouse models [50-52]. Stem cells in the ovarian surface epithelium are an important subject to be studied further in terms of their possible regenerative role: potential oogenesis in vitro, differentiation into different types of somatic cells for regenerative medicine, and better understanding of the manifestation and potentially a more individualized treatment of aggressive ovarian epithelial cancers in these patients.

\section{Acknowledgments}

The authors would like to thank gynecologists-Dr. Branko Cvjeticanin, Assistant Professor Dr. Andrej Vogler, Professor Dr. Helena Meden-Vrtovec, University Medical Centre Ljubljana, and all three patients that provided ovarian tissue for this research, and to Ms. Sabine Conrad, MTA, University of Tuebingen, Germany, for her technical assistance in Fluidigm analyses. They also greatly acknowledge the Slovenian Research Agency (ARRS, Grant J3-0415/Irma Virant-Klun) and the German Federal Ministry of Education and Research (BMBF, Grant 01GN1001/Thomas Skutella) for the financial support, and all others supporting this research.

\section{References}

[1] N. Auersperg, C. H. Siemens, and S. E. Myrdal, "Human ovarian surface epithelium in primary culture," In Vitro, vol. 20, no. 10, pp. 743-755, 1984.

[2] C. H. Siemens and N. Auersperg, "Serial propagation of human ovarian surface epithelium in tissue culture," Journal of Cellular Physiology, vol. 134, no. 3, pp. 347-356, 1988.

[3] P. A. Kruk, S. L. Maines-Bandiera, and N. Auersperg, "A simplified method to culture human ovarian surface epithelium," Laboratory Investigation, vol. 63, no. 1, pp. 132-136, 1990.

[4] O. Gubbay, W. Guo, M. T. Rae et al., "Anti-inflammatory and proliferative responses in human and ovine ovarian surface epithelial cells," Reproduction, vol. 128, no. 5, pp. 607-614, 2004.

[5] M. T. Rae, D. Niven, H. O. D. Critchley, C. R. Harlow, and S. G. Hillier, "Antiinflammatory steroid action in human ovarian surface epithelial cells," Journal of Clinical Endocrinology and Metabolism, vol. 89, no. 9, pp. 4538-4544, 2004.

[6] F. Jiang, B. O. Saunders, E. Haller, S. Livingston, S. V. Nicosia, and W. Bai, "Conditionally immortal ovarian cell lines for investigating the influence of ovarian stroma on the estrogen sensitivity and tumorigenicity of ovarian surface epithelial cells," In Vitro Cellular and Developmental Biology, vol. 39, no. 7, pp. 304-312, 2003.

[7] J. M. J. Piek, J. C. Dorsman, A. Shvarts et al., "Cultures of ovarian surface epithelium from women with and without a hereditary predisposition to develop female adnexal carcinoma," Gynecologic Oncology, vol. 92, no. 3, pp. 819-826, 2004.

[8] D. G. Rosen, G. Yang, R. C. Bast, and J. Liu, "Use of rastransformed human ovarian surface epithelial cells as a model for studying ovarian cancer," Methods in Enzymology, vol. 407, pp. 660-676, 2005.

[9] T. G. Shepherd, B. L. Thériault, E. J. Campbell, and M. W. Nachtigal, "Primary culture of ovarian surface epithelial cells and ascites-derived ovarian cancer cells from patients," Nature Protocols, vol. 1, no. 6, pp. 2643-2649, 2006.

[10] N. Ahmed, E. W. Thompson, and M. A. Quinn, "Epithelialmesenchymal interconversions in normal ovarian surface epithelium and ovarian carcinomas: an exception to the norm," Journal of Cellular Physiology, vol. 213, no. 3, pp. 581$588,2007$.

[11] S. Okamoto, A. Okamoto, T. Nikaido et al., "Mesenchymal to epithelial transition in the human ovarian surface epithelium focusing on inclusion cysts," Oncology Reports, vol. 21, no. 5, pp. 1209-1214, 2009.

[12] Y. Zhu, M. Nilsson, and K. Sundfeldt, "Phenotypic plasticity of the ovarian surface epithelium: TGF- $\beta 1$ induction of Epithelial to Mesenchymal Transition (EMT) in vitro," Endocrinology, vol. 151, no. 11, pp. 5497-5505, 2010.

[13] N. J. Bowen, L. D. Walker, L. V. Matyunina et al., "Gene expression profiling supports the hypothesis that human ovarian surface epithelia are multipotent and capable of serving as ovarian cancer initiating cells," BMC Medical Genomics, vol. 2, article 71, 2009.

[14] J. A. Parrott, G. Kim, and M. K. Skinner, "Expression and action of kit ligand/stem cell factor in normal human and bovine ovarian surface epithelium and ovarian cancer," Biology of Reproduction, vol. 62, no. 6, pp. 1600-1609, 2000.

[15] P. M. Motta and S. Makabe, "Germ cells in the ovarian surface during fetal development in humans. A three-dimensional microanatomical study by scanning and transmission electron microscopy," Journal of Submicroscopic Cytology, vol. 18, no. 2, pp. 271-290, 1986.

[16] P. M. Motta and S. Makabe, "Development of the ovarian surface and associated germ cells in the human fetus. A correlated study by scanning and transmission electron microscopy," Cell and Tissue Research, vol. 226, no. 3, pp. 493-510, 1982.

[17] P. M. Motta and S. Makabe, "Elimination of germ cells during differentiation of the human ovary: an electron microscopic study," European Journal of Obstetrics Gynecology and Reproductive Biology, vol. 22, no. 5-6, pp. 271-286, 1986.

[18] W. Waldeyer, Ein Beitrag zur Anatomie und Entwicklungsgeschichte der Sexualorgane, Engelmann, Leipzig, Germany, 1870.

[19] H. M. Kingery, "Oogenesis in the white mouse," Journal of Morphology, vol. 30, pp. 261-315, 1917.

[20] A. Allen, "Ovogenesis during sexual maturity," American Journal of Anatomy, vol. 31, pp. 439-481, 1923.

[21] H. M. Evans and O. Swezy, "Ovogenesis and the normal follicular cycle in adult mammalia," Memorial of the University of California, vol. 9, pp. 119-224, 1931.

[22] A. Bukovsky, M. Svetlikova, and M. R. Caudle, "Oogenesis in cultures derived from adult human ovaries," Reproductive Biology and Endocrinology, vol. 3, article 17, 2005.

[23] I. Virant-Klun, N. Zech, P. Rozman et al., "Putative stem cells with an embryonic character isolated from the ovarian surface epithelium of women with no naturally present follicles and oocytes," Differentiation, vol. 76, no. 8, pp. 843-856, 2008.

[24] I. Virant-Klun, P. Rozman, B. Cvjeticanin et al., "Parthenogenetic embryo-like structures in the human ovarian surface epithelium cell culture in postmenopausal women with no 
naturally present follicles and oocytes," Stem Cells and Development, vol. 18, no. 7, p. 1109, 2009.

[25] I. Virant-Klun and T. Skutella, "Stem cells in aged mammalian ovaries," Aging, vol. 2, no. 1, pp. 3-6, 2010.

[26] S. Parte, D. Bhartiya, J. Telang et al., "Detection, characterization, and spontaneous differentiation in vitro of very small embryonic-like putative stem cells in adult mammalian ovary," Stem Cells and Development, vol. 20, no. 8, pp. 1451-1464, 2011.

[27] D. Goswami and G. S. Conway, "Premature ovarian failure," Human Reproduction Update, vol. 11, no. 4, pp. 391-410, 2005.

[28] J. P. Liu and H. Li, "Telomerase in the ovary," Reproduction, vol. 140, no. 2, pp. 215-222, 2010.

[29] K. Spanel-Borowski, "Footmarks of innate immunity in the ovary and cytokeratin-positive cells as potential dendritic cells," Advances in Anatomy Embryology and Cell Biology, vol. 209, pp. 1-126, 2011.

[30] S. Löffler, L. C. Horn, W. Weber, and K. Spanel-Borowski, "The transient disappearance of cytokeratin in human fetal and adult ovaries," Anatomy and Embryology, vol. 201, no. 3, pp. 207-215, 2000.

[31] H. Serke, C. Vilser, M. Nowicki et al., "Granulosa cell subtypes respond by autophagy or cell death to oxLDL-dependent activation of the oxidized lipoprotein receptor 1 and toll-like 4 receptor," Autophagy, vol. 5, no. 7, pp. 991-1003, 2009.

[32] H. H. Ortega, N. R. Salvetti, L. A. Müller et al., "Characterization of cytoskeletal proteins in follicular structures of cows with cystic ovarian disease," Journal of Comparative Pathology, vol. 136, no. 4, pp. 222-230, 2007.

[33] M. Z. Ratajczak, E. K. Zuba-Surma, M. Wysoczynski, J. Ratajczak, and M. Kucia, "Very small embryonic-like stem cells: characterization, developmental origin, and biological significance," Experimental Hematology, vol. 36, no. 6, pp. 742-751, 2008.

[34] M. Z. Ratajczak, E. K. Zuba-Surma, D. M. Shin, J. Ratajczak, and M. Kucia, "Very small embryonic-like (VSEL) stem cells in adult organs and their potential role in rejuvenation of tissues and longevity," Experimental Gerontology, vol. 43, no. 11, pp. 1009-1017, 2008.

[35] M. Z. Ratajczak, M. Kucia, J. Ratajczak, and E. K. Zuba-Surma, "A multi-instrumental approach to identify and purify very small embryonic like stem cells (VSELs) from adult tissues," Micron, vol. 40, no. 3, pp. 386-393, 2009.

[36] W. Wojakowski, M. Tendera, M. Kucia et al., "Cardiomyocyte differentiation of bone marrow-derived Oct-4 +CXCR4+SSEA-1+ very small embryonic-like stem cells," International Journal of Oncology, vol. 37, no. 2, pp. 237-247, 2010.

[37] D. M. Shin, R. Liu, I. Klich et al., "Molecular signature of adult bone marrow-purified very small embryonic-like stem cells supports their developmental epiblast/germ line origin," Leukemia, vol. 24, no. 8, pp. 1450-1461, 2010.

[38] V. M. Y. Ding, P. J. Boersema, L. Y. Foong et al., “Tyrosine phosphorylation profiling in FGF-2 stimulated human embryonic stem cells," PLoS ONE, vol. 6, no. 3, article e17538, 2011.

[39] L. R. Nelson and S. E. Bulun, "Estrogen production and action," Journal of the American Academy of Dermatology, vol. 45, no. 3, supplement, pp. S116-S124, 2001.

[40] J. Smitz, H. M. Picton, P. Platteau et al., "Principal findings from a multicenter trial investigating the safety of follicularfluid meiosis-activating sterol for in vitro maturation of human cumulus-enclosed oocytes," Fertility and Sterility, vol. 87, no. 4, pp. 949-964, 2007.

[41] I. J. M. Duijkers, W. N. P. Willemsen, H. M. G. Hollanders, C. J. C. M. Hamilton, C. M. G. Thomas, and H. M. Vemer, "Follicular fluid hormone concentrations after ovarian stimulation using gonadotropin preparations with different $\mathrm{FSH} / \mathrm{LH}$ ratios. II. Comparison of hMG and recombinant FSH," International Journal of Fertility and Women's Medicine, vol. 42, no. 6, pp. 431-435, 1997.

[42] A. Velazquez, A. Reyes, J. Chargoy, and A. Rosado, "Amino acid and protein concentrations of human follicular fluid," Fertility and Sterility, vol. 28, no. 1, pp. 96-100, 1977.

[43] E. V. Bokal, K. F. Tacer, M. Vrbnjak et al., "Follicular sterol composition in gonadotrophin stimulated women with polycystic ovarian syndrome," Molecular and Cellular Endocrinology, vol. 249, no. 1-2, pp. 92-98, 2006.

[44] U. Ulug, E. Turan, S. B. Tosun, H. F. Erden, and M. Bahceci, "Comparison of preovulatory follicular concentrations of epidermal growth factor, insulin-like growth factor-I, and inhibins $\mathrm{A}$ and $\mathrm{B}$ in women undergoing assisted conception treatment with gonadotropin-releasing hormone (GnRH) agonists and GnRH antagonists," Fertility and Sterility, vol. 87, no. 4, pp. 995-998, 2007.

[45] K. Ko, P. Reinhardt, N. Tapia et al., "Brief report: evaluating the potential of putative pluripotent cells derived from human testis," Stem Cells, vol. 29, no. 8, pp. 1304-1309, 2011.

[46] N. Tapia, M. J. Araúzo-Bravo, K. Ko, and H. R. Schöler, "Concise review: challenging the pluripotency of human testis-derived ESC-like cells," Stem Cells, vol. 29, no. 8, pp. 1165-1169, 2011.

[47] U. Riekstina, I. Cakstina, V. Parfejevs et al., "Embryonic stem cell marker expression pattern in human mesenchymal stem cells derived from bone marrow, adipose tissue, heart and dermis," Stem Cell Reviews and Reports, vol. 5, no. 4, pp. 378386, 2010.

[48] Y. Kuroda, M. Kitada, S. Wakao et al., "Unique multipotent cells in adult human mesenchymal cell populations," Proceedings of the National Academy of Sciences of the United States of America, vol. 107, no. 19, pp. 8639-8643, 2010.

[49] O. Trubiani, S. F. Zalzal, R. Paganelli et al., "Expression profile of the embryonic markers nanog, OCT-4, SSEA-1, SSEA4, and Frizzled-9 receptor in human periodontal ligament mesenchymal stem cells," Journal of Cellular Physiology, vol. 225, no. 1, pp. 123-131, 2010.

[50] K. Zou, Z. Yuan, Z. Yang et al., "Production of offspring from a germline stem cell line derived from neonatal ovaries," Nature Cell Biology, vol. 11, no. 5, pp. 631-636, 2009.

[51] J. Pacchiarotti, C. Maki, T. Ramos et al., "Differentiation potential of germ line stem cells derived from the postnatal mouse ovary," Differentiation, vol. 79, no. 3, pp. 159-170, 2010.

[52] S. P. Gong, S. T. Lee, E. J. Lee et al., "Embryonic stem celllike cells established by culture of adult ovarian cells in mice," Fertility and Sterility, vol. 93, no. 8, pp. 2594-2601, 2010. 


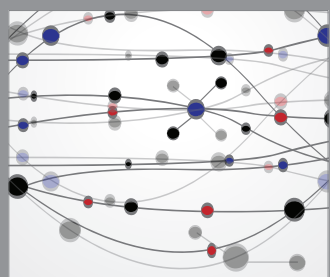

The Scientific World Journal
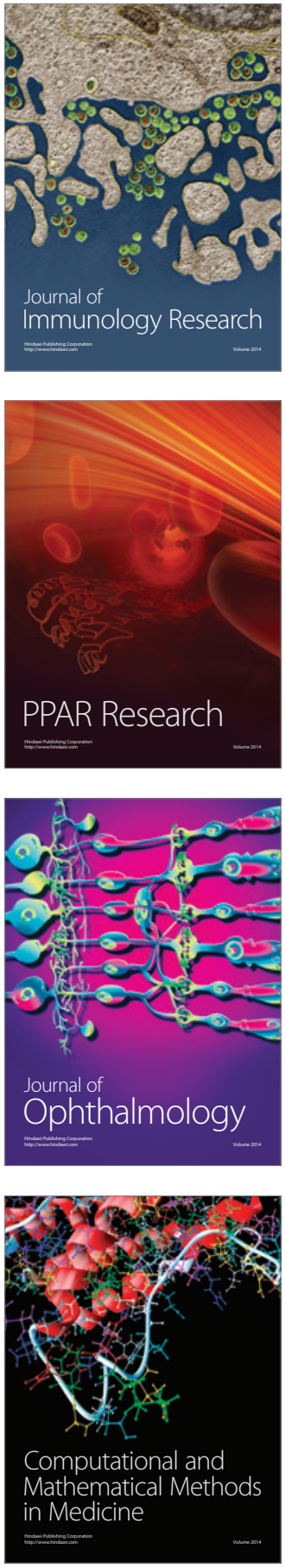

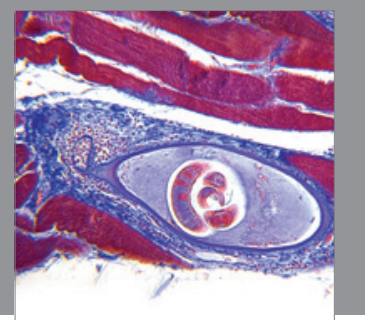

Gastroenterology

Research and Practice
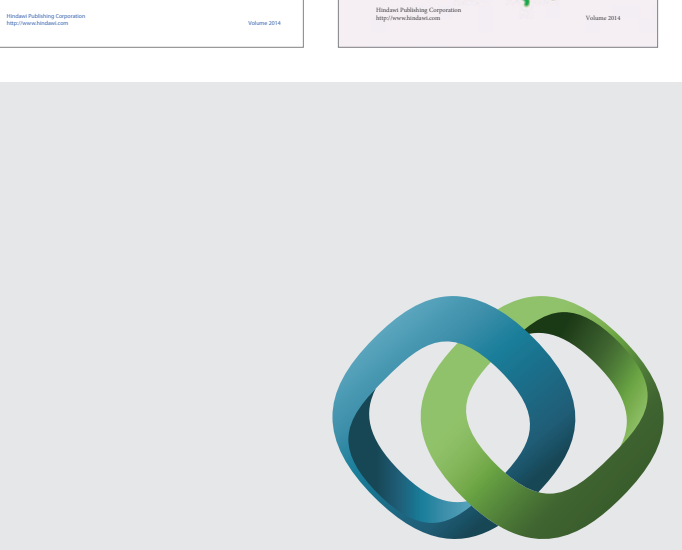

\section{Hindawi}

Submit your manuscripts at

http://www.hindawi.com
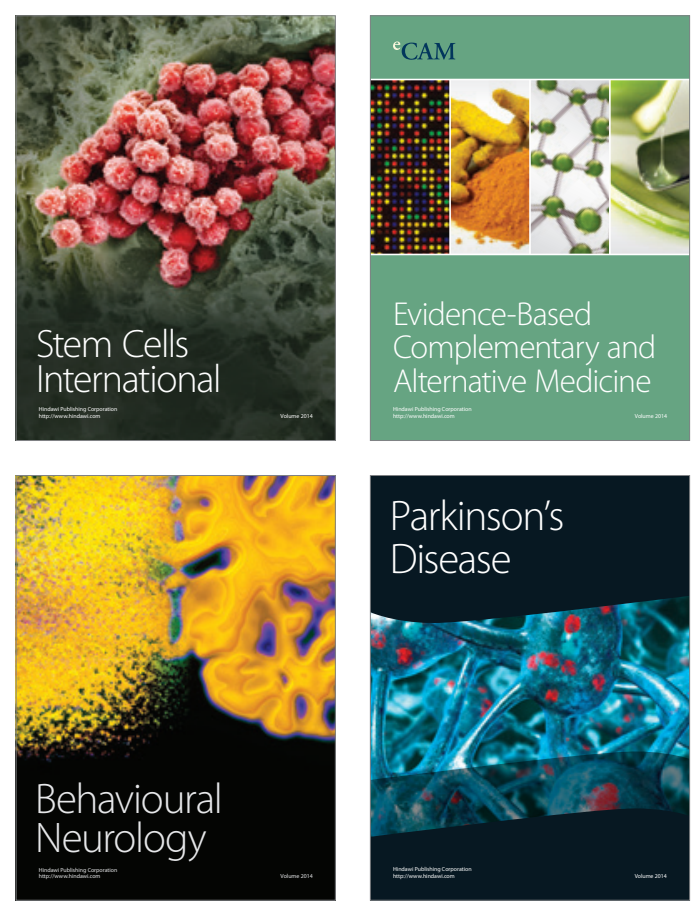

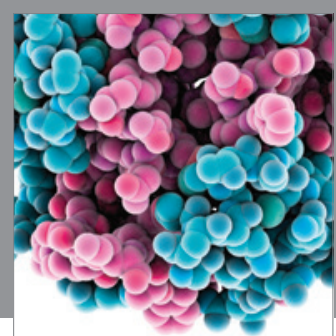

Journal of
Diabetes Research

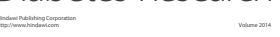

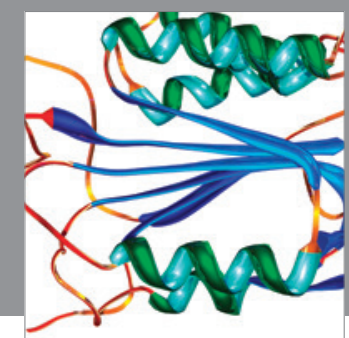

Disease Markers
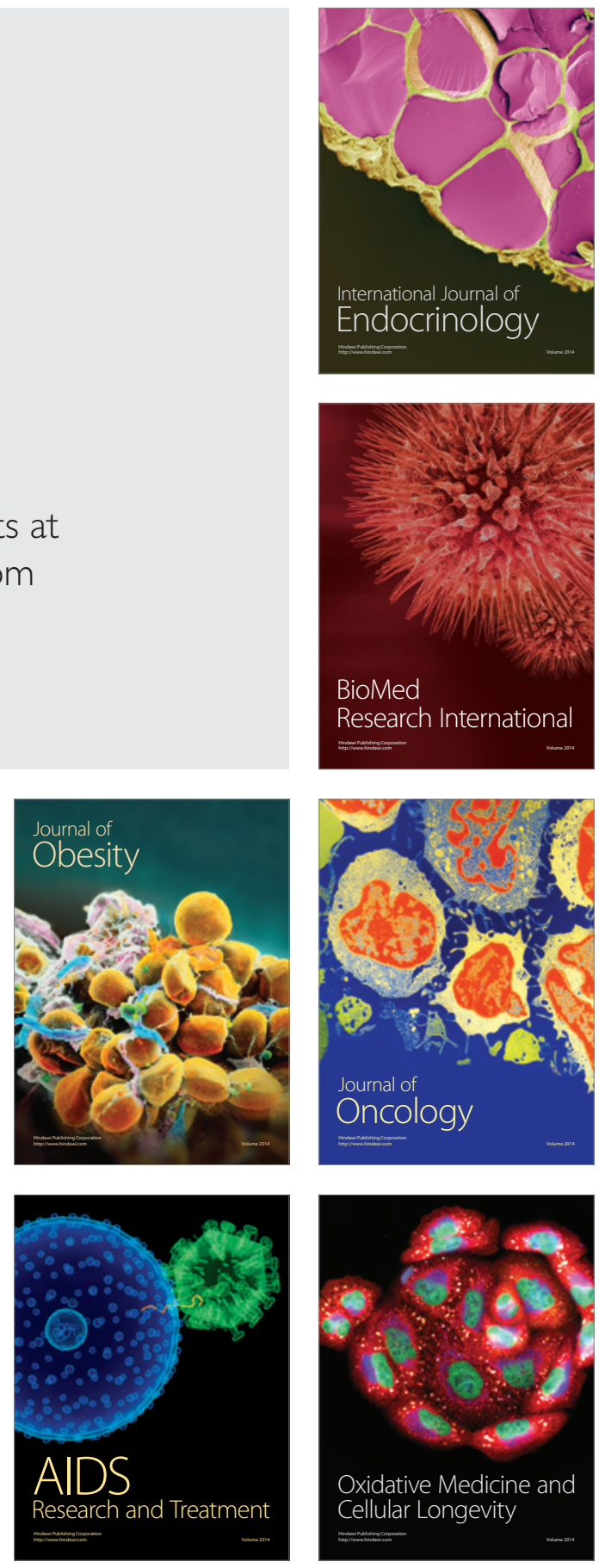